\title{
FORMAÇÕES XERÓFILAS NO CERRO DO DIOGO, NA LOCALIDADE DE RODEIO VELHO, SANTANA DA BOA VISTA, RS.
}

\author{
Rodrigo Corrêa Pontes $^{(a)}$, Maurício Rizzatti ${ }^{(b)}$, Cibele Stefanno Saldanha ${ }^{(c)}$, Mauro Kumpfer \\ Werlang ${ }^{(d)}$
}

(a) Doutorando em Geografia, Universidade Federal de Santa Maria, Email: rodrigocorreapontes@gmail.com

(b) Mestrando em Geografia, Universidade Federal de Santa Maria, Email: geo.mauricio.rizzatti@gmail.com

(c) Mestranda em Geografia, Universidade Federal de Santa Maria, Email: cibele2012stefanno@ gmail.com

(d) Prof. Dr. do Departamento de Geociências, Universidade Federal de Santa Maria, Email: wermakwer@gmail.com

\section{Eixo: Biogeografia, manejo de áreas naturais e protegidas: conservação da biodiversidade}

\section{Resumo:}

O estudo a seguir busca apontar a relevância do Cerro do Diogo, na localidade de Rodeio Velho, a oeste do município de Santana da Boa Vista, na Serra do Sudeste do Rio Grande do Sul, RS. A área de estudo apresenta diversas geoformas com interessantes aspectos fitogeográficos e geomorfológicos tais como afloramentos rochosos e escarpamentos, promovendo a existência de ambientes adequados para o estabelecimento de elementos florísticos de caráter xerófito. Esse tipo específico de vegetação presente nesses litobiomas é representado majoritariamente por espécies relictuais como bromeliáceas e cactáceas que perduraram em ambientes que reproduzem condições similares aos seus ecossistemas originais pretéritos. Baseado em fundamentos da Fitogeografia e da Geomorfologia, o trabalho tem como objetivo identificar, caracterizar e relacionar a flora xerofítica com os respectivos ambientes constituintes da paisagem da área de estudo, demonstrando a importância da preservação e conservação desses diminutos e disjuntos pontos de significativa biodiversidade.

Palavras chave: Bioma Pampa; Fitogeografia; Geomorfologia; Rio Grande do Sul.

\section{Introdução}

A perturbação antrópica e o uso intensivo da terra têm colocado em risco a existência de vários táxons da flora brasileira. Nesse sentido a busca pela preservação e/ou conservação de espécies é pertinente através de estudos e levantamentos que busquem reconhecer as espécies e seus respectivos ecossistemas, podendo desta forma delinear um panorama ambiental e apontar suas eminentes ameaças perante o problema presente. A expansão dos centros urbanos, crescimento das cidades e principalmente modernização do homem no campo são os principais impactos antrópicos em ambientes naturais, esses que previamente não eram utilizados pelo o homem. Paulatinamente, dessa maneira, inúmeros ecossistemas têm sido impactados de forma quase que imediata, dos quais muitos já se encontram fragilizados pela sua própria natureza devido a complexos processos ecológicos. Muitas dessas espécies presentes nesses nichos ecológicos são representadas por espécies endêmicas e ameaçadas de extinção, como o caso de representantes das famílias Bromeliaceae e Cactaceae, testemunhos de paleoclimas que, ao longo dos 
milhares de anos, ficaram isolados em locais que reproduzem as condições necessárias para sua permanência e reprodução.

A diversidade geológica e geomorfológica do Rio Grande do Sul apresenta uma beleza cênica ímpar, além de fomentar inúmeros objetos para estudos científicos. Assim como outros elementos da paisagem, essas variadas formas presentes no relevo favorecem a formação de diversos ambientes propícios para o surgimento de endemismos florísticos. Na Serra do Sudeste do Rio Grande do Sul, mais precisamente na localidade de Rodeio Velho, a oeste do município de Santana da Boa Vista, encontram-se expressivos morrotes com o topo plano, constituídos de areno-conglomerados oriundos de depósitos datados do Paleozóico, resultante de complexos processos de evolução geológica e geomorfológica. Esse conjunto geomorfológico apresenta feições ruiniformes com fraturas, janelas de ablação, entre outros, ambientes perfeitos para abrigar bromeliáceas e cactáceas. Estas áreas são conhecidas como refúgios ecológicos, que por aspectos geomorfológicos (declividade) e pedológicos (solos litólicos) o homem ainda não conseguiu impactá-los ao avançar sobre eles. Estes locais geralmente são afloramentos rochosos, escarpamentos abruptos e solos muito pobres em nutrientes, onde não é rentável e por esta razão há pouco interesse para a agricultura.

\section{Objetivos}

Diante a atual problemática ambiental, este trabalho possui como objetivo geral a identificação dos endemismos de cactáceas na geoforma situada na localidade de Rodeio Velho, a oeste do município de Santana da Boa Vista, Rio Grande do Sul, buscando enfatizar a importância ecológica e fitogeográfica deste frágil ecossistema.

Como objetivos específicos, o trabalho busca: a) identificar e representar cartograficamente a área de estudo; b) descrever a situação em que se encontra a área de estudo e c) inventariar o contingente de espécies endêmicas e relictuais na área de estudo, confirmando a importância fitogeográfica da área

\section{Fundamentação teórica}

Nos estudos de Rambo (1956) e Marchiori (2002) afirma-se que a vegetação do estado do Rio Grande do Sul situa-se em um período transitório induzido pelos padrões climáticos firmados entre os períodos do Pleistoceno e do Holoceno. Marchiori (2004) propõe que para deduzir a distribuição da vegetação do Estado, no caso da transição campo - floresta deve-se dar ênfase na biologia das espécies representativas dessas áreas, assim como suas relações com o relevo. 
No interior da vegetação florestal podem ocorrer pequenas áreas com vegetação aberta, como campos e campos rupestres, verdadeiras ilhas ricas em endemismo, apresentando geralmente espécies heliófilas e xerófitas. Estes espaços podem ser afloramentos rochosos no campo de pequena à vasta extensão e até escarpas íngremes com altura variável. A vegetação em afloramentos horizontais é muito suscetível às ações do homem, principalmente relacionado ao uso da terra como meio agrícola. A vegetação encontrada nas escarpas é certamente bem mais preservada, em razão do seu difícil acesso e desta forma, livre das pressões antrópicas diretas.

Waechter (2002) cita gêneros chaquenhos presentes na flora do Rio Grande do Sul, como Trithrinax (Arecaceae), Dyckia (Bromeliaceae), Echinopsis, Frailea, Gymnocalycium e Parodia (Cactaceae), entre outras. Estes elementos migraram da Província Chaquenha (Argentina e Paraguai) durante tempos áridos no passado geológico, quando foi propício para seu avanço, colonizando amplamente ambientes xerófitos como afloramentos rochosos, solos arenosos e até escarpas abruptas.

Este tipo de vegetação está diretamente associado a uma formação campestre (mais aberta) do que a formação florestal (mais fechada) por necessidades fisiológicas de sobrevivência. Nestas composições relictuais, predominam elementos xerófitos, adaptados a escassez de água e nutrientes, à insolação e à temperatura. Esses elementos são mais representados pelas famílias botânicas Bromeliaceae, Cactaceae, entre outras. Estudos sobre a dinâmica climática do Pleistoceno explicam a presença dessas xerófitas nos tempos atuais.

Segundo Marchiori (2004) a vegetação no Estado é formada por campos e florestas, em constante competição por espaço e influenciada por fatores ambientais. As áreas campestres, sendo mais antigas e a maioria em nossa paisagem, são relictos do clima do Pleistoceno, onde atualmente sofre o avanço das florestas em razão do clima do Holoceno correspondente a temperaturas mais quentes e umidade.

Os campos também são resultantes da combinação de fatores climáticos geológicos e geomorfológicos. Marchiori (2004) admite que campos e florestas são formações relacionadas a climas antagônicos e que a existência de ambas ocorre em razão de sua biologia e sua relação com o relevo. Lindmann (1906, p. 164165) menciona diversos elementos xerófitos presentes na flora do Rio Grande do Sul, inclusive cactáceas. Rambo (1956) elaborou diversos estudos fitogeográficos sobre a vegetação do Rio Grande do Sul, inclusive visitando locais com presença de espécies xerófitas.

É indispensável comentar sobre a fragilidade destes ecossistemas, que algumas ocasiões não permitem o emprego de métodos tradicionais de monoculturas e silvicultura. A exploração destas áreas é limitada devido à grande abundante rochosidade e a pouca oferta de nutrientes no solo. Mesmo assim, populações estão sendo devastadas. 
Conforme Troppmair (2012) a presença de formações superficiais e cobertura vegetal está intimamente relacionada com estudos paleoclimáticos do Pleistoceno. Haffer (1969) edificou o que ficou conhecido como a Teoria dos Refúgios Pleistocênicos, fundamentada através da interpretação da flutuação climática de uma fase semi-árida e dos processos evolutivos das paisagens neotropicais da América do Sul durante o Pleistoceno Terminal. De acordo com Troppmair (2012) a teoria fundamenta-se nos processos evolutivos considerando os estudos sobre paleoclimas.

Segundo Ab'Saber (1977), durante o Pleistoceno Terminal, dois vastos espaços abertos na América do Sul foram presentes, relacionando as paisagens com fatores climáticos, edáficos e paleogeográficos: a Diagonal Arréica Sul-Americana e o Corredor de Savanas Sul-Americanas, ambas pontes de ligação entre áreas secas e convergindo para um ponto de encontro localizado na região do Chaco.

Desta forma, um amplo corredor árido ocidental surgiu, influenciando nos arranjos fitogeográficos da América do Sul as vegetações abertas predominavam sobre as imensas formações florestais. Kern (1982) também cita que a reconstrução de rotas migratórias e estudos palinológicos do Quaternário são escassos, tornando hipotética a reconstrução das paisagens deste período. Mesmo assim, o autor infere que só logo após a mudança das correntes marítimas e o aumento da umidade no ar é que a floresta retomou a colonização das áreas campestres.

Ab’Saber (1979) cita que as afirmações sobre oscilações climáticas do Quaternário, durante o último período glacial denominado de Würm-Winscosin, fundamentam-se em observações ecológicas (aridez rochosa, campos com a presença de cactáceas, refúgios de flora), testemunhos geomorfológicas (bolsões residuais, mini-enclaves e pedimentos de terraços fluviais) e testemunhos sedimentológicos (crostas ferruginosas, linhas de pedra, paleossolos). O referido geógrafo também enfatiza os mini-enclaves de vegetação xerófita, onde características residuais conservaram-se perante a alteração para um clima mais úmido. Conforme Bigarella (2007) durante o período glacial, em razão desse ambiente frio e seco, a cobertura vegetal fechada passou por um significativo decréscimo em razão da competitividade com as espécies de vegetação aberta, devido as condições sub-úmidas e semi-áridas, com predominância de ambientes ecológicos de cerrado e caatinga.

As repetidas mudanças climáticas tiveram sobre a distribuição da cobertura vegetal regional, causando em uma duração relativamente curta, contínuas contrações e expansões tanto de vegetações fechadas (florestas) quanto de vegetações abertas (campos). Essa dinâmica de contrações e expansões ocasionaram a fragmentação de uma área contínua e que paulatinamente foram confinadas em áreas cada vez menores (refúgios) onde a permanência da espécie foi estabelecida em razão de condições propicias para a sua sobrevivência. 
XVII Simpósio Brasileiro

de Geografia Física Aplicada

I Congresso Nacional

de Geografia Física
OS DESAFIOS DA GEOGRAFIA FÍSICA NA FRONTEIRA DO CONHECIMENTO

Instituto de Geociências - Unicamp

Campinas - SP

28 de Junho à 02 de Julho de 2017

Ab'Saber (1979) afirma que grande parte das coxilhas do Uruguai e do Rio Grande do Sul foram

submetidas a climas secos do Quaternário e que alguns segmentos foram recobertos por formações xerófitas, com bromeliáceas e cactáceas, associado à uma floresta rarefeita, com árvores tortuosas e estepe arbustiva.

Rambo (1956) e Marchiori (2002) afirmam que o atual clima do Rio Grande do Sul é propício para a expansão da vegetação florestal. Entretanto, dentro desta ampla fitofisionomia predominante, há a ocorrência de ilhas de vegetação, tipicamente de formações abertas, verdadeiros resquícios de uma vegetação anterior e típica de um clima árido ou semi-árido. Klein (1975) enfatiza que diversos elementos presentes na flora atual, típicos de formações abertas, expressam estruturas curiosas, adaptados à seca e que estas características não teriam função em nosso clima atual.

\section{Metodologia}

O trabalho iniciou-se com a adoção da proposta metodológica da proposição da análise sistêmica da paisagem e o método hipotético-dedutivo para uma maior aproximação da realidade com a pesquisa. Após a seleção da área de estudo, buscou-se um levantamento bibliográfico sobre a temática proposta a investigação dos objetivos, para desta maneira definir os subsídios para o desenvolvimento do tema, orientação teórico-metodológica e organização dos procedimentos ao longo do trabalho. A revisão bibliográfica realizou-se a partir de leituras sobre fitogeografia, onde foram consultados artigos, dissertações e livros os quais permitiram definir o marco conceitual deste trabalho. Os procedimentos metodológicos foram organizados em quatro fases: a) localização geográfica, delimitação da área de estudo e sua caracterização; b) coleta de dados à campo e investigação (levantamento); c) organização e interpretação dos dados coletados e d) elaboração dos resultados e conclusões.

A área de estudo do (Figura 1) encontra-se na localidade de Rodeio Velho, a oeste do município de Santana da Boa Vista, Com a definição da área de estudo, iniciou-se a delimitação da área e de localização geográfica, baseando-se na carta topográfica da Diretoria do Serviço Geográfico do Exército Brasileiro, correspondente à Carta Topográfica de Minas do Camaquã, Folha SH.22-Y-A-V-3, MI-2996/3, Rio Grande do Sul, na escala 1:50.000, localizada entre as coordenadas geográficas $30^{\circ} 45^{\prime}$ e $31^{\circ} 00^{\prime}$ de Latitude Sul e $53^{\circ} 30^{\prime}$ e $53^{\circ} 15^{\prime}$ de Longitude Oeste. 


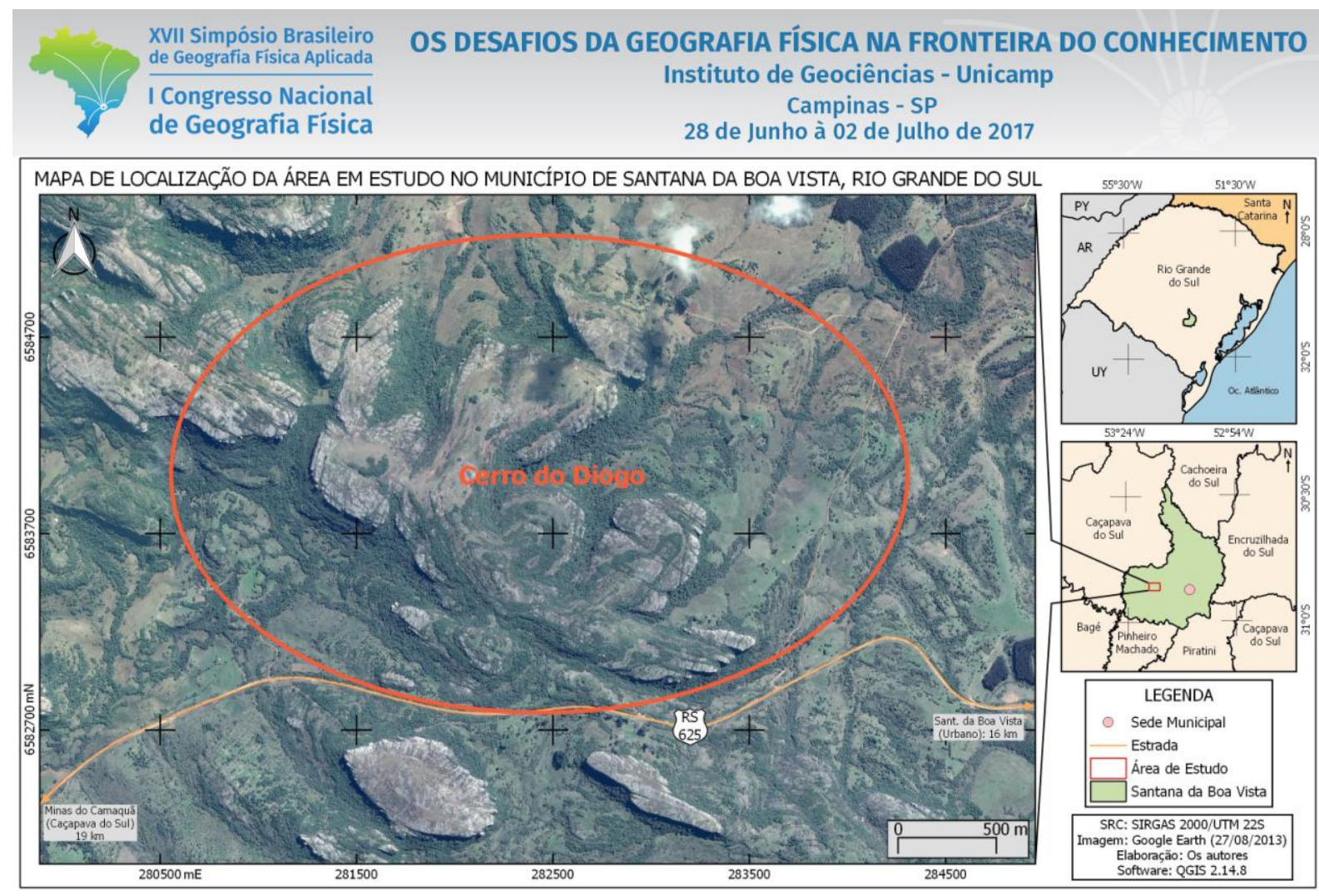

Figura 1 - Mapa de localização da área de estudo. Elaboração: Autores.

De acordo com a proposta de Ross (1996) a geomorfologia na área de estudo corresponde a macroforma estrutural denominada Bacia Sedimentar do Paraná, onde é reconhecida a grande unidade escultural como Escudo Sul-riograndense, um planalto de origem intrusiva e posteriormente recoberto por sedimentos e extrusões vulcânicas. Posteriormente sua superfície foi aplainada e dissecada pelos diversos processos geológicos. A área de estudo está associada a um relevo suave ondulado a fortemente ondulado, o que não proporciona uma homogeneidade na distribuição dos elementos climáticos, contribuindo para a formação de microclimas. Nas encostas de morros, morrotes e arroios é possível encontrar escarpamentos A altitude é compreendida entre os valores de 335 metros acima do nível do mar.

De acordos com dados coletados em campo e o referencial teórico da Companhia de Pesquisa de Recursos Minerais (2014), a litologia na área de estudo é formada por rochas da Formação Pedra Pintada e Formação Pedra Varzinha, depositadas há cerda de 460 - 510 milhões de anos, pertencentes ao grupo Guaritas da Bacia do Camaquã, depositados no Paleozóico Inferior.

A Formação Pedra Pintada possui estratificação típica de paleodunas eólicas (devido seu ângulo de inclinação) de ambiente desértico, apresentando arenitos equigranulares finos a médios, bem selecionados, arenitos conglomeráticos e pelito, com estratos cruzados acanalados de grande porte. Os arenitos são constituídos de quartzo e feldspato, sendo que as distintas colorações são resultantes da oxidação dos sedimentos e percolação das águas meteóricas. A formação ostenta a direção de suas estratificações de 


\section{OS DESAFIOS DA GEOGRAFIA FÍSICA NA FRONTEIRA DO CONHECIMENTO \\ Instituto de Geociências - Unicamp \\ Campinas - SP \\ 28 de Junho à 02 de Julho de 2017}

forma organizada devido a direção dos ventos, os quais tendiam para o sudoeste. Depositada de forma concordante sobre as unidades da Formação Pedra Pintada, encontra-se a Formação Varzinha, composta majoritariamente por arenitos finos, conglomerado polimítico e pelito de origem aluvial seguido por acumulações eólicas (basal) recobertas por uma sucessão lacustre e deltas associados (topo). O morrote apresenta o aspecto ruiniforme, forma esta que foi gerada através do desgaste por fraturamentos e falhamentos (Figura 2). A presença de janelas de ablação é resultante da ação eólica e hídrica durante climas pretéritos.

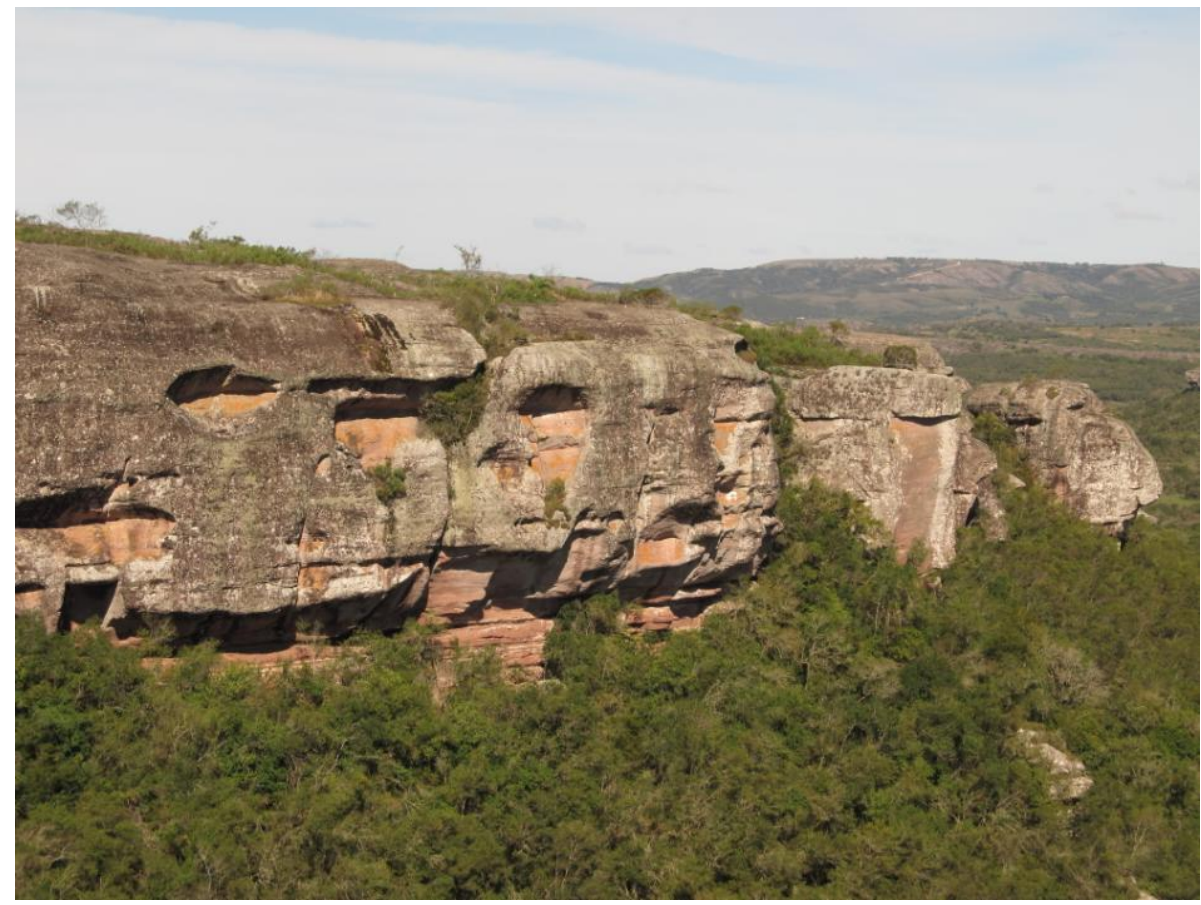

Figura 2 - Escarpamento do morrote, apresentando janelas de ablação. Fonte: Autores.

Os dados foram coletados com um aparelho receptor de GPS (Sistema de Posicionamento Global), modelo eTrexLegendHCx. Foram definidos os limites da área, formando um polígono. Utilizou-se o Datum WGS84 e o programa Google Earth 6.1. As coordenadas geográficas coletadas em campo pelo receptor GPS foram inseridas no programa GPS Trackmaker Professional (GTM PRO, versão 4.8) sobre a base cartográfica vetorial contínua do Rio Grande do Sul, esta com escala de 1:50.000, na carta topográfica referida acima, constituindo um mapa de localização.

Para a base cartográfica foram utilizados arquivos digitais para uso em SIG, Base Cartográfica digital do Rio Grande do Sul, escala 1:250.000. Foi utilizada uma imagem SRTM (Shuttle Radar Topography Mission), com resolução de 90 metros. A adição da base cartográfica com dados coletados a campo permitiu a criação do mapa base da área em estudo. A partir desse mapa base foi desenvolvido o 
mapa hipsométrico da área. Em seguida, após a interpretação de imagens de satélite fornecidas pelo programa Google Earth e do mapa geológico produzido pela Companhia de Pesquisa de Recursos Minerais (2010), caracterizou-se as litologias presentes. Durante trabalho de campo buscou-se a confirmação ou correção, dos contatos das formações geológicas presentes. Posteriormente todas essas informações foram selecionadas e reunidas através da confecção de mapas demonstrando as características ambientais da área de estudo. Os mapas foram confeccionados através do programa ArcGis 10, onde foram digitalizadas as curvas de nível, apresentando as cotas altimétricas da área de estudo.

No que diz respeito da análise da vegetação, foi adotado o método de Caminhamento, proposto por Filgueiras et al. (1994), que consiste em três etapas: a) reconhecimento dos tipos de vegetação na área a ser amostrada, b) elaboração da lista das espécies encontradas e c) análise dos resultados. A identificação das espécies vegetais foi realizada in situ quando as espécies se encontravam férteis e posteriormente com auxílio de fotografias e literatura especializada conforme os trabalhos de Hunt (2006) e Carneiro et al. (2016).

\section{Resultados e discussões}

Foram encontrados na área de estudo ao todo dezesseis táxons consideradas relictuais, sendo da Família Arecaceae: Trithrinax brasiliensis Martius; Família Bromeliaceae: Aechmea recurvata (Klotzsch) L. B. Smith Dyckia jonesiana T. Strehl, Dyckia selloa (Koch) Baker, Tillandsia bella T. Strehl, Tillandsia lorentziana Griseb; Família Cactaceae: Cereus hildmannianus K. Schumann, Echinopsis oxygona (Link) Zuccarini, Frailea gracillima (Lemaire) Britton \& Rose, Gymnocalycium horstii Buining, Opuntia elata Salm-Dyck, Parodia neohorstii (Theunissen) N. P. Taylor, Parodia ottonis (Lehmann) N. P. Taylor, Parodia rudibuenenekeri subsp. glomerata (Gerloff) Hofacker, Parodia scopa (Sprengel) N. P. Taylor e Parodia werneri Hofacker.

As espécies foram encontradas em afloramentos rochosos horizontais, em material intemperizado e no topo ou nas encostas dos morrotes, geramente em vertentes voltadas para o norte, onde há maior incidência da luz solar. Também foram encontradas espécies em afloramentos rochosos próximos a base dos morrotes, onde, esses se encontram cercados por campos abertos ou áreas mais florestadas com a presença de alguma vegetação arbustiva.

Ressalta-se que Dyckia jonesiana, Gymnocalycium horstii, Parodia nothohorstii, Parodia rudibuenenekeri subsp. glomerata e Parodia werneri são espécies endêmicas da região. 
Cereus hildmannianus, único representante deste gênero no Rio Grande do Sul, pertencente a subfamília Cactoideae (Cereeae) é uma espécie frequente na área de estudo, habitando afloramentos rochosos horizontais e escarpamentos com fraturas ou janelas de ablação. Possui o corpo colunar com o porte arbustivo ou arbóreo e apresenta flores tubulares branco-rosadas e noturnas. Seus frutos podem ser amarelos ou avermelhados. É uma espécie indicadora de solos rasos, onde também podem ocorrer cactáceas globulares.

Echinopsis é uma espécie globular, que se torna cilíndrica com o passar dos anos, com forte brotação, com flores em forma de tubo, noturnas. Possui ampla variação morfológica e ampla distribuição geográfica no Rio Grande do Sul. Foi encontrado sobre afloramentos rochosos, a pleno sol.

Frailea gracillima, Cactoideae (Notocacteae) foi encontrada em poucos indivíduos, em populações fragmentadas, dispersas afloramentos rochosos horizontais e inclinados, geralmente associado a musgos e liquens. O gênero é representado por espécies de pequeno porte com o corpo globular-cilíndico, 3-4 cm de diâmetro, com flores amarelas, cleistogâmicas e frutos pubescentes.

No que diz respeito à Gymnocalycium horstii, espécie endêmica da região da área de estudo possui corpo globular, cálice desprovido de lã e cerdas, flores brancas a branco-róseas e possui dimorfismo sexual. Foram encontradas apenas populações pontuais com um número pequeno de indivíduos, preferencialmente habitando os escarpamentos rochosos.

A respeito de Opuntia elata, foram encontrados exemplares habitando afloramentos rochosos. O táxon de caráter arbustivo apresenta o corpo segmentado em cladódios, flores laranjas e frutos vináceos. É importante enfatizar que essa espécie tem uma importante relação ecológica com as demais espécies globulares, onde seus espinhos longos protegem as espécies menores, encontradas em sua proximidade.

Conforme o levantamento, o gênero Parodia é o predominante na área de estudo, com maior número de indivíduos, totalizando cinco espécies. São caracterizados pelo corpo globular à cilíndrico, costelas tuberculadas, espinhos pungentes, flores diurnas amarelas (mais raramente roséas), não tubulares.

Parodia rudibuenenekeri subsp. glomerata e P. scopa foram as espécies encontradas em diversos pontos, podendo ser simpáticas. Frequentemente ocorrem em escarpamentos orientados para o Norte, podendo também, de forma acidental, ocorrer em afloramentos rochosos horizontais. As espécies são muito similares, possuem espinhos radiais brancos, com espinhos centrais avermelhados, mas são distinguíveis por peculiaridades presente nas peças florais, mais precisamente na coloração do pistilo.

Parodia neohorstii foi encontrada em apenas dois locais, onde uma população encontrava-se ligeiramente degradada pela ação de ovinos e javalis. A outra população apresenta centena de exemplares, sendo que 


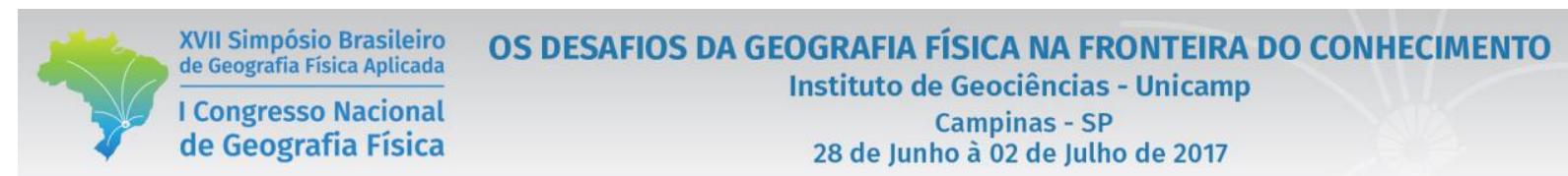

esta está sendo impactada pelos ovinos, devido a observação de exemplares danificados e deslocados. Esta espécie tem o hábito solitário, é provida de espinhos brancos pungentes e possui flores são amarelas. Ocorre tipicamente em afloramentos rochosos horizontais, com a presença de liquens entre seixos destacados de rochas conglomeráticas.

Gymnocalycium horstii, Parodia neohorstii e Parodia rudibuenenekeri subsp. glomerata (Figura 3) são espécies endêmicas da região do Cerro do Diogo.

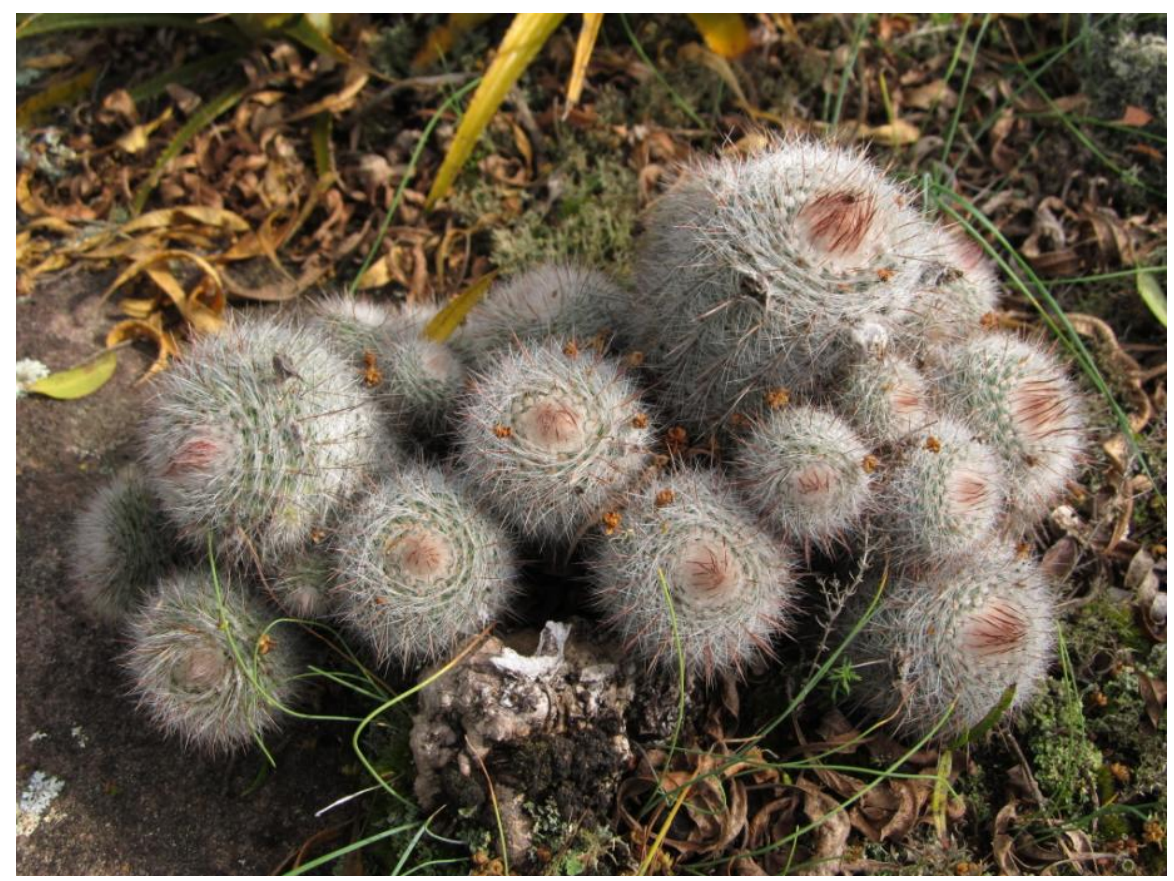

Figura 3 - Parodia rudibuenenekeri subsp. glomerata na escarpa do morrote da área de estudo. Fonte: Autores.

Parodia ottonis foi encontrada em diversos pontos, tanto em afloramentos rochosos quanto em solos mais humosos cobertos por gramíneas, em grandes agrupamentos. Apresenta corpo globular verde escuro, podendo crescer em agrupamentos e possui flores amarelas.

Por último, Parodia werneri tem uma ocorrência mais restrita na área de estudo, apenas em três populações muito reduzidas. Apresentou uma grande variabilidade morfológica, principalmente a questão do comprimento dos espinhos. A espécie cresce em afloramentos rochosos, algumas vezes cobertos por musgos e liquens.

Sobre as bromeliáceas, exemplares Aechmea recurvata foram encontrados de forma abundante, tanto como rupícolas quanto saxícolas, sobre blocos de rocha em cima de afloramentos rochosos e escarpamentos, demonstrando uma preferência por luminosidade e tipo de substrato. 
Dyckia selloa dispõem suas folhas em forma de rosetas, providas de espinhos podendo apresentar inflorescências com flores amarelas. Foram encontrados alguns agrupamentos. Apresentam hábito terrestre, rupícola e saxícola. Dyckia jonesiana encontra-se no mesmo tipo de habitat, mas habitando apenas afloramentos rochosos com musgos.

Tillandsia lorentziana e Tillandsia bella foram encontradas apenas nos escarpamentos da área do estudo. São espécies simpátricas, e apesar de que $T$. bella é mais frequente em vertentes mais sombrias de orientação sul. T. lorentziana é uma espécie mais frequente nas vertentes de orientação norte.

Trithrinax brasiliensis é considerada uma espécie endêmica e rara do sul do Brasil. A distribuição geográfica é fragmentada em populações pequenas, severamente ameaçadas pelas atividades antrópicas como fogo e pecuária, ocorrendo em formações abertas como campos, geralmente rupestres, com vertentes ligeiramente inclinadas e com grande exposição solar.

Analisando as espécies cactáceas desses afloramentos rochosos pode-se perceber as diversas formas anatômicas devido à adaptação (presença corpo costelado, de espinhos, florescimento em elevadas temperaturas). Holz (2003) relata que as mudanças no tipo de ambiente no passado influenciavam na distribuição e na morfologia da vegetação. Em razão de pressões ambientais no passado as espécies adquiriram estruturas que permitem sua sobrevivência em um substrato seco, com uma raiz para se sustentar e tirar nutrientes, além de habitar os mais distintos nichos ecológicos.

Esses protagonistas, constituintes do ecossistema atual, apresentam características morfológicas adaptadas em tempos passados e são como testemunhos das restrições a que foram submetidos no passado.

\section{Considerações finais}

Segundo as constatações levantadas a campo, conclui-se que a localidade de Rodeio Velho ostenta uma rica biodiversidade xerófita da família Arecaceae, Bromeliaceae, Cactaceae. O conjunto florístico é formando por dezesseis espécies, algumas endêmicas como Trithrinax brasiliensis (Arecaceae), Aechmea recurvata, Dyckia jonesiana, D. selloa, Tillandsia bella, T. lorentziana (Bromeliaceae); Cereus hildmannianus, Echinopsis oxygona, Frailea gracillima, Gymnocalycium horstii, Opuntia elata, Parodia neohorstii, P.ottonis, P. rudibuenenekeri subsp. glomerata, P. scopa e P. werneri (Cactaceae). A presença desses elementos está relacionada com a abundância de afloramentos rochosos e escarpamentos presentes nas geoformas, ambientes ideais para espécies relictuais, muitas delas endêmicas, com demandas peculiares de sobrevivência como aridez, calor, luminosidade e drenagem. Desta forma a pesquisa 
contribuiu para o conhecimento da flora o município de Santana da Boa Vista e espera-se que esse trabalho venha colaborar com estudos posteriores.

\section{Bibliografia}

AB'SÁBER, A. N. Espaços ocupados pela expansão dos climas secos na América do Sul, por ocasião dos períodos glaciais quaternários. Paleoclimas, São Paulo, n. 3, p. 1-19, 1977.

AB'SÁBER, A. N. Os mecanismos da desintegração das paisagens tropicais no Pleistoceno. Efeitos paleoclimáticos do período Würm-Wisconsin no Brasil. São José do Rio Preto: Inter Facies, 1979, n. 4, p. 1-19.

BIGARELLA, J. J.; BECKER, R. D; SANTOS, G. F. Estrutura e origem das Paisagens tropicais e subtropicais. 2. ed. Florianópolis: Ed. da UFSC, 2007. (Volume 1).

CARNEIRO, A. M; SINGER, R. F; RAMOS, R. A; NILSON; A. D. Cactos do Rio Grande do Sul. Fundação Zoobotânica do Rio Grande do Sul, 2016. 224 p

FILGUEIRAS, T; et. al. Método de Caminhamento: um método expedito para levantamentos florísticos qualitativo. Caderno de Geociências. Rio de Janeiro: IBGE, n.12, out/dez, 1994. p. 39-44

HAFFER, J. Speciation in Amazonian forest birds. Science, Washington, n. 165, p. 131-137, 1969.

HOLZ, M. Do mar ao deserto: a evolução no Rio Grande do Sul no tempo geológico. 2. ed. Porto Alegre: UFRGS 2003. $142 \mathrm{p}$.

HUNT, D. R.; TAYLOR, N. P.; CHARLES, G. The new cactus lexicon. Milborne Port: Dh Books, 2006. 374 p

KERN, A. A. Paleopaisagens e povoamento pré-histórico do Rio Grande do Sul. Estudos ibero-americanos, Porto Alegre, v. 8, n. 2, p. 153-208, 1982.

LINDMAN,C. A. M. A vegetação do Rio Grande do Sul (Brasil Austral). Porto Alegre: Livraria Universal de Echenique Irmãos \& Cia, 1906. 356 p.

MAPA GEOLÓGICO DO ESTADO DO RIO GRANDE DO SUL. Companhia de Pesquisa de Recursos Minerais. Porto Alegre, Serviço Geológico do Brasil, 2006. 1 mapa, color. Disponível em: $<\mathrm{http} / / /$ geobank.sa.cprm.gov.br/pls/publicogeobank.download.downloadlayouts?p_webmap=N>. Acesso em 13 jan .2017 .

MARCHIORI, J. N. C. Fitogeografia do Rio Grande do Sul: enfoque histórico e sistemas de classificação. Porto Alegre: EST, 2002.

MARCHIORI, J. N. C. Fitogeografia do Rio Grande do Sul. Campos Sulinos. Porto Alegre: EST, 2004. 110 p.

MARCHIORI, J. N. C. Fitogeografia do Rio Grande do Sul: Embasamento florístico. Porto Alegre: EST, 2006. 40p.

RAMBO, B. A fisionomia do Rio Grande do Sul. Ensaio de monografia natural. São Leopoldo: 3. ed, Ed. da UNISINOS, 1956. $456 \mathrm{p}$.

ROMARIZ, D. A. Biogeografia: temas e conceitos. São Paulo: Scortecci, 2012. 199 p.

ROOS, J. L. S. Geografia do Brasil. 6. ed. São Paulo: Edusp, v. 1, 1996. 552 p.

TROPPMAIR, H. Biogeografia e meio ambiente. 9 ed. Rio de Janeiro: Technical Books, 9. ed. 2012. 281 p.

WAECHTER, J. L. Padrões geográficos na flora atual do Rio Grande do Sul. Ciência \& Ambiente. Santa Maria: n. 24, jan./jun. 2002. p. 93-108 